\title{
LEUCINE : AN EFFICIENT AND GREEN AMINO ACID CATALYST FOR CONVERSION OF ALDEHYDES AND KETONES INTO GEM- DIHYDROPEROXIDES WITH $\mathrm{H}_{2} \mathrm{O}_{2}$
}

Davood Azarifar ${ }^{\star}, \mathrm{a}$, Omolbanin Badalkhani ${ }^{\mathrm{a}}$, Kaveh Khosravi ${ }^{\mathrm{b}}$, Younes Abbasi ${ }^{\mathrm{a}}$

${ }^{a}$ Faculty of Chemistry, Bu-Ali Sina University, Zip Code 65178, Hamedan, Iran

${ }^{b}$ Department of Chemistry, Faculty of science, Arak University, Arak 38156-8-8349, Iran

$$
\begin{gathered}
\text { azarifarn@gmail.com } \\
\text { o.badalkhani@yahoo.com } \\
\text { khosravi.kaveh@gmail.com } \\
\text { younes.abbasi@yahoo.com }
\end{gathered}
$$

"Corresponding author: E-mail: azarifar@basu.ac.ir; Tel: +98(811)8380647

\section{ABSTRACT}

Leucine amino acid, has been explored as an effective catalyst for conversion of ketones and aldehydes into corresponding gem-dihydroperoxides using 30\% aqueous hydrogen peroxide in acetonitrile at room temperature. The reactions proceed smoothly within short periods of time to provide the respective gem-dihydroperoxides in excellent yields. Mild reaction conditions, low reaction times, high yields, low environmental impact, use of non-expensive, recyclable and green catalyst are the main merits of the present method.

\section{Keywords}

Gem-dihydroperoxide; leucine; amino acid; hydrogen peroxide; aldehyde; ketone

\section{Academic Discipline And Sub-Disciplines}

Organic chemistry

\section{SUBJECT CLASSIFICATION}

Synthetic Organic Chemistry

\section{Council for Innovative Research}

\author{
Peer Review Research Publishing System
}

Journal: Journal of Advances in Chemistry

Vol. 11, No. 2

editorjaconline@gmail.com 


\section{INTRODUCTION}

Gem-dihydroperoxides (DHPs) are considered as stable derivatives of ketones and aldehydes [1], which have been of considerable interest because of their relevance to peroxidic antimalarial drugs [2]. Also, these compounds are important intermediates in the synthesis of a number of classes of peroxides including tetraoxanes [3], silateraoxans [4], spirobisperoxyketals [5], bisperoxyketals [6], and 1,2,4,5-tetraoxacycloalkanes [7]. Gem-dihydroperoxides have also been employed as initiators for radical polymerization reactions [8], as precursors for synthesis of dicarboxylic acid esters [9], and as reagents for oxidation reactions such epoxidation of $\alpha, \beta$-unsaturated ketones [10], enantioselective oxidation of 2 substituted 1,4-naphtoquinones [11], oxidation of sulfides [12], and as suitable oxidants in other synthetic organic reactions [27]. Three major methods reported for the synthesis of gem-dihydroperoxides are: (i) ozonolysis of ketone eneol ethers or $\alpha$-olefines in the presence of aqueous $\mathrm{H}_{2} \mathrm{O}_{2}$ [7a, 13], (ii) reaction of ketals with $\mathrm{H}_{2} \mathrm{O}_{2}$ in the presence of tungstic acid [14], or $\mathrm{BF}_{3} . \mathrm{Et}_{2} \mathrm{O}$ [15] and (iv) peroxidation of ketones using an acidic solvent [16]. However, many of these methods have certain drawbacks including the use of concentrated $\mathrm{H}_{2} \mathrm{O}_{2}$ and excess acid, low yield, limited substrate range and production of mixtures of peroxidic products [17]. Also, poor selectivity and the presence of ozone sensitive groups in the substrates are further limitations in ozonolysis reaction. In order to avoid such limitations, recently, reactions of ketones and aldehydes with $\mathrm{H}_{2} \mathrm{O}_{2}$ in the presence of Lewis acids in organic solvents have been reported. Amongst the Lewis acids, $I_{2}$ [18], ceric ammonium nitrate (CAN) [19], CSA [20], $\mathrm{NaHSO}_{4} \cdot \mathrm{SiO}_{2}$ [21], $\mathrm{Re}_{2} \mathrm{O}_{7}$ [22] and $\mathrm{PMA}^{2}$ [23] have been reported as the catalysts in the synthesis of gem-dihydroperoxides with aqueous $\mathrm{H}_{2} \mathrm{O}_{2}$. With respect to the increasing concern on the environmental issue and also to comply with the principles of the green chemistry [24], we are encouraged in the present research to examine the catalytic efficiency of leucine amino acid as a green and inexpensive catalyst for the synthesis of gem-dihydroperoxides from aldehydes and ketones using hydrogen peroxide. It is important to note that, so far no report on the use of amino acids as catalysts in the synthesis of gem-dihydroperoxides from aldehydes and ketones has appeared in the literature.

\section{EXPERIMENTAL}

\subsection{Material and instruments}

Solvents and chemicals were obtained from Aldrich and Merck chemical companies and used without purification. Melting points were determined in open capillary tubes in a Stuart $\mathrm{SMP}_{3}$ apparatus and uncorrected. ${ }^{1} \mathrm{H}$ and ${ }^{13} \mathrm{C} N M R$ spectra were recorded on a JEOL FX $90 \mathrm{Q}$ spectrometer at 90 and $22.5 \mathrm{MHz}$ respectively using $\mathrm{Me}_{4} \mathrm{Si}$ as an internal standard. IR spectra were recorded on a Perkin Elmer GX FT IR spectrometer ( $\mathrm{KBr}$ pellets).

Caution: Although we did not encounter any problem with these reactions, peroxidic compounds are potentially explosive and should be handled with precautions; all reactions should be carried out behind a safety shield inside a fume hood and transition metal salts or heating should be avoided

\subsection{General procedure for conversion of ketones and aldehydes into corresponding gem- dihydroperoxides}

To a mixture of carbonyl compound 1 (1 mmol), and leucine (14 mg, $0.1 \mathrm{mmol}$ ) in MeCN (4 mL) was added $30 \%$ aqueous $\mathrm{H}_{2} \mathrm{O}_{2}(2 \mathrm{~mL})$, and the mixture was stirred at room temperature for an appropriate time (Table 2). After completion of the reaction as monitored by TLC, the product was extracted with chloroform $(3 \times 4 \mathrm{~mL})$. Then, the combined organic layer was dried over anhydrous $\mathrm{MgSO}_{4}$, filtered and evaporated under reduced pressure. The residue was purified by silica-packed column chromatography (hexane-EtOAc) to afford pure gem-dihydroperoxides (Table 2). The products were characterized on the basis of their physical and spectral $\left({ }^{1} \mathrm{H},{ }^{13} \mathrm{C}\right.$ NMR and IR) data and compared with those reported in the literature (Table 2). The characteristic data for some representative and new products are given below.

Methyl-(naphthalen-1-yl)-1,1-dihydroperoxide (2k). Colorless oil; IR (KBr), v: 3324, 3052 (O-H stretching), 2922, 2853, 1594, 1573, 1508, 1461, 1356, 1279, 1240, 1192, 1128, 941, 863, 802, 775, $591 \mathrm{~cm}^{-1}$; MS (FABMS, $\left.70 \mathrm{ev}\right): \mathrm{m} / \mathrm{z}$ (\%): 243 $(\mathrm{M}+\mathrm{Na})^{+} ;{ }^{1} \mathrm{H}-\mathrm{NMR}\left(\mathrm{CDCl}_{3}, 90 \mathrm{MHz}\right): \delta 8.83-8.75$ (brs, $\left.2 \mathrm{H}, \mathrm{OOH}\right), 8.10-7.20(\mathrm{~m}, 7 \mathrm{H}, \mathrm{Ar}-\mathrm{H}), 2.66\left(\mathrm{~s}, 3 \mathrm{H}, \mathrm{CH}_{3}\right) ;{ }^{13} \mathrm{C}-\mathrm{NMR}$ $\left(\mathrm{CDCl}_{3}, 22.5 \mathrm{MHz}\right): \delta 136.0,134.4,131.1,129.9,127.8,126.6,125.5,123.0,107.0,20.5$; Anal. Calcd for $\mathrm{C}_{12} \mathrm{H}_{12} \mathrm{O}_{4}: \mathrm{C}_{\text {, }}$ $65.45 ; \mathrm{H}, 5.45 \%$. Found: C, 65.42; H, 5.40\%.

(4-Bromophenyl)methylene-1,1-dihydroperoxide (2t). Colorless solid; mp 88-90 ${ }^{\circ} \mathrm{C}$; IR (KBr), v: $3426,3085(\mathrm{O}-\mathrm{H}$ stretching), 2909, 1608, 1528, 1411, 1353, 1236, 1195, 1083, 973, 856, 828, 753, 706, $601 \mathrm{~cm}^{-1}$; MS (FABMS, $\left.70 \mathrm{ev}\right): \mathrm{m} / \mathrm{z}$ $(\%): 258(\mathrm{M}+\mathrm{Na})^{+} ;{ }^{1} \mathrm{H}-\mathrm{NMR}\left(\mathrm{CDCl}_{3}, 90 \mathrm{MHz}\right): \delta 9.96$ (brs, 2H, OOH), 7.90-7.00 (m, 4H, Ar-H), $6.26(\mathrm{~s}, 1 \mathrm{H}, \mathrm{CH}) ;{ }^{13} \mathrm{C}-\mathrm{NMR}$ $\left(\mathrm{CDCl}_{3}, 22.5 \mathrm{MHz}\right): \delta$ 141.0, 132.5, 130.5, 120.0, 111.0; Anal. Calcd for $\mathrm{C}_{7} \mathrm{H}_{7} \mathrm{BrO}_{4}: \mathrm{C}, 35.74 ; \mathrm{H}, 2.97 \%$. Found: $\mathrm{C}, 35.72$; $\mathrm{H}, 2.94 \%$.

(4-Flourophenyl)methylene-1,1-dihydroperoxide (2u). Colorless solid; mp 110-112 ${ }^{\circ} \mathrm{C}$; IR (KBr), v: $3464,3082(\mathrm{O}-\mathrm{H}$ stretching), 2905, 1625, 1601, 1564, 1453, 1353, 1303, 1071, 1025, 844, 720, $685 \mathrm{~cm}^{-1}$; MS (FABMS, $\left.70 \mathrm{ev}\right): \mathrm{m} / \mathrm{z}(\%):$ $197(\mathrm{M}+\mathrm{Na})^{+} ;{ }^{1} \mathrm{H}-\mathrm{NMR}\left(\mathrm{CDCl}_{3}, 90 \mathrm{MHz}\right): \delta 9.21$ (brs, $\left.2 \mathrm{H}, \mathrm{OOH}\right), 8.14-7.14(\mathrm{~m}, 4 \mathrm{H}, \mathrm{Ar}-\mathrm{H}), 6.14(\mathrm{~s}, 1 \mathrm{H}, \mathrm{CH}) ;{ }^{13} \mathrm{C}-\mathrm{NMR}$ $\left(\mathrm{CDCl}_{3}, 22.5 \mathrm{MHz}\right): \delta$ 161.62, 137.0, 128.5, 118.5, 112.0; Anal. Calcd for $\mathrm{C}_{7} \mathrm{H}_{7} \mathrm{FO}_{4}: \mathrm{C}, 48.27 ; \mathrm{H}, 4.02 \%$. Found: $\mathrm{C}, 48.23$; $\mathrm{H}, 3.97 \%$.

(2-Methoxyphenyl)methylene-1,1-dihydroperoxide (2v). Colorless oil; IR (KBr), v: 3226, 3085 (O-H stretching), 2853 , 1647, 1603, 1493, 1465, 1372, 1245, 1177, 1017, 844, $758 \mathrm{~cm}^{-1}$; MS (FABMS, $\left.70 \mathrm{ev}\right): \mathrm{m} / \mathrm{z}(\%): 209(\mathrm{M}+\mathrm{Na})^{+} ;{ }^{1} \mathrm{H}-\mathrm{NMR}$ $\left(\mathrm{CDCl}_{3}, 90 \mathrm{MHz}\right): \delta 9.35$ (brs, $\left.2 \mathrm{H}, \mathrm{OOH}\right), 8.18-6.84(\mathrm{~m}, 4 \mathrm{H}, \mathrm{Ar}-\mathrm{H}), 6.04(\mathrm{~s}, 1 \mathrm{H}, \mathrm{CH}), 4.05\left(\mathrm{~s}, 3 \mathrm{H}, \mathrm{OCH}_{3}\right) ;{ }^{13} \mathrm{C}_{-N M R}\left(\mathrm{CDCl}_{3}\right.$ 
$22.5 \mathrm{MHz}): \delta 157.4,139.1,128.5,123.0,118.5,102.0,57.5$; Anal. Calcd for $\mathrm{C}_{8} \mathrm{H}_{10} \mathrm{O}_{5}$ : C, 51.61; H, 5.37\%. Found: C, $51.57 ; \mathrm{H}, 5.34 \%$.

(Pyridin-3-yl)methylene-1,1-dihydroperoxide (2x). Colorless solid; Mp. > $160{ }^{\circ} \mathrm{C}$; IR (KBr), v: 3410, 2941, 1635, 1450, 1393, 1139, 996, 640, $521 \mathrm{~cm}^{-1}$; ${ }^{1} \mathrm{H}-\mathrm{NMR}$ (d $\mathrm{d}_{6}$-DMSO, $90 \mathrm{MHz}$ ): $\delta 9.75$ (brs, 2H, OOH), 8.71-7.23 (m, 4H, Ar-H), $7.18(\mathrm{~s}$ $1 \mathrm{H}, \mathrm{CH}) ;{ }^{13} \mathrm{C}-\mathrm{NMR}\left(\mathrm{CDCl}_{3}, 22.5 \mathrm{MHz}\right): \delta$ 150.9, 142.1, 137.6, 124.4, 118.2, 53.8; Anal. Calcd for $\mathrm{C}_{6} \mathrm{H}_{7} \mathrm{NO}_{4}: \mathrm{C}_{,} 45.86 ; \mathrm{H}$, 4.46 ; N, 8.91\%. Found: C, 45.48; H, 4.42; N, 8.65\%.

(Quinolin-2-yl)methylene-1,1-dihydroperoxide (2y). Yello solid; Mp. 138-140 ̊ ; IR (KBr), v: 3425, 3250, 2958, 1660, 1629, 1600, 1375, 1355, 1111, 807, 779, $636 \mathrm{~cm}^{-1}$; ${ }^{\mathrm{H}-\mathrm{NMR}}\left(\mathrm{CDCl}_{3}, 90 \mathrm{MHz}\right)$ : $\delta 8.95$ (brs, 2H, OOH), 7.49-8.25 (m, $6 \mathrm{H}$, $\mathrm{Ar}-\mathrm{H}), 6.61(\mathrm{~s}, 1 \mathrm{H}, \mathrm{CH}) ;$ Anal. Calcd for $\mathrm{C}_{10} \mathrm{H}_{9} \mathrm{NO}_{4}$ : C, 57.97; $\mathrm{H}, 4.35 ; \mathrm{N}, 6.76 \%$. Found: $\mathrm{C}, 57.82 ; \mathrm{H}, 4.32 ; \mathrm{N}, 6.73 \%$.

\section{RESULTS AND DISCUSSION}

In continuation of our efforts to explore new and benign catalysts for the synthesis of gem-dihydroperoxides [25], and their applications as versatile and high potent oxidants in various organic transformations [26], herein, we wish to introduce the leucine amino acid as a cheap, green and effective catalyst in the synthesis of gem-dihydroperoxides from ketones and aldehydes with $30 \%$ aqueous $\mathrm{H}_{2} \mathrm{O}_{2}$ at room temperature (scheme 1 ).
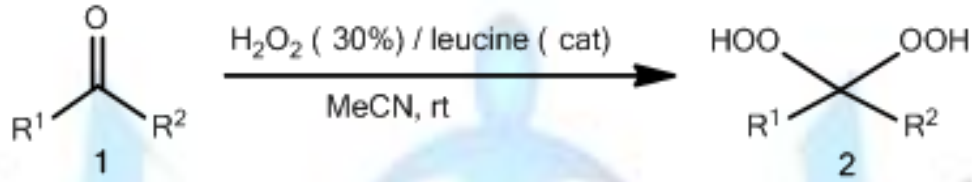

Scheme 1. Leucine-catalyzed oxidative conversion of aldehydes and ketones to gem-dihydroperoxides with $\mathrm{H}_{2} \mathrm{O}_{2}(30 \%)$.

In an effort to establish the reaction conditions, various reaction parameters were studied for the preparation of 1,1 dihydroperoxycyclohexane through the model reaction of cyclohexanone with $30 \%$ aqueous $\mathrm{H}_{2} \mathrm{O}_{2}$ under the catalytic effect of leucine using different solvents such as $\mathrm{CH}_{2} \mathrm{Cl}_{2}, \mathrm{Et}_{2} \mathrm{O}, \mathrm{AcOEt}, \mathrm{CH}_{3} \mathrm{CN}$ and the results are summarized in Table 1. As seen in this Table, the best result in terms of yield and reaction time was obtained using MeCN as the solvent of choice and $10 \mathrm{~mol} \%$ catalyst loading at room temperature (entry 5). The importance of the catalyst in this reaction was verified by conductiong the reaction in the absence of leucine that resulted in trace amount of the product (entry 10).

\begin{tabular}{|c|c|c|c|c|c|}
\hline \multicolumn{7}{|c|}{ Table 1. Screening the reaction parameters for the formation of 1,1- } \\
dihydroperoxycyclohexane
\end{tabular}

With optimized conditions in hand (aq. $30 \% \mathrm{H}_{2} \mathrm{O}_{2}, 10 \mathrm{~mol} \%$ catalyst, $\mathrm{MeCN}$, rt) we began to study the scope of the reaction using a range of aliphatic and aromatic aldehydes and ketones as summarized in Table 2. As shown in Table 2, 
the aliphatic ketones 1a-f generally react faster than the aromatic ones $\mathbf{1 g - k}$ to afford the corresponding gemdihydroperoxides comparatively in higher yields. Similarly, the aromatic aldehydes $\mathbf{1 p}$-y were quantitatively converted to the corresponding DHPs with relatively longer reaction times. However, this procedure proved to be unsuitable for the preparation of DHPs from the aromatic ketones $\mathbf{1 I}$ and $\mathbf{1 m}$ which remained untouched after ca $3 \mathrm{~h}$ reaction under the optimized conditions. This can be possibly explained by the strong resonance stabilization effects on the carbonyl group. It was interesting to note that, the addition of only one molecule of hydrogen peroxide to the carbonyl group occurs in reactions of aliphatic aldehydes such as $\mathbf{1 n}$ and $\mathbf{1 0}$ to result in the formation of 1,1-hydroxyhydroperoxide derivatives instead of the expected DHPs compounds.

\begin{tabular}{|c|c|c|c|c|c|c|}
\hline Entry & Ketone \& Aldehyde 1 & Product $^{\mathrm{D}} \mathbf{2}$ & Time (min) & Yield (\%) & $\operatorname{Mp}\left({ }^{\circ} \mathrm{C}\right)$ & Ref. \\
\hline a & & & 20 & 96 & oil & [20] \\
\hline b & & & 15 & 98 & oil & [23a] \\
\hline c & & & 13 & 97 & $62-64$ & [22] \\
\hline d & & & 15 & 98 & oil & [18a] \\
\hline e & & & 20 & 92 & oil & [19] \\
\hline$f$ & & & 18 & 95 & oil & [19] \\
\hline g & & & 180 & 80 & 76-78 & [19] \\
\hline h & & & & 65 & oil & [26h] \\
\hline $\mathbf{i}$ & & & 150 & 80 & oil & [26h] \\
\hline j & & & 290 & 65 & oil & [18b] \\
\hline
\end{tabular}




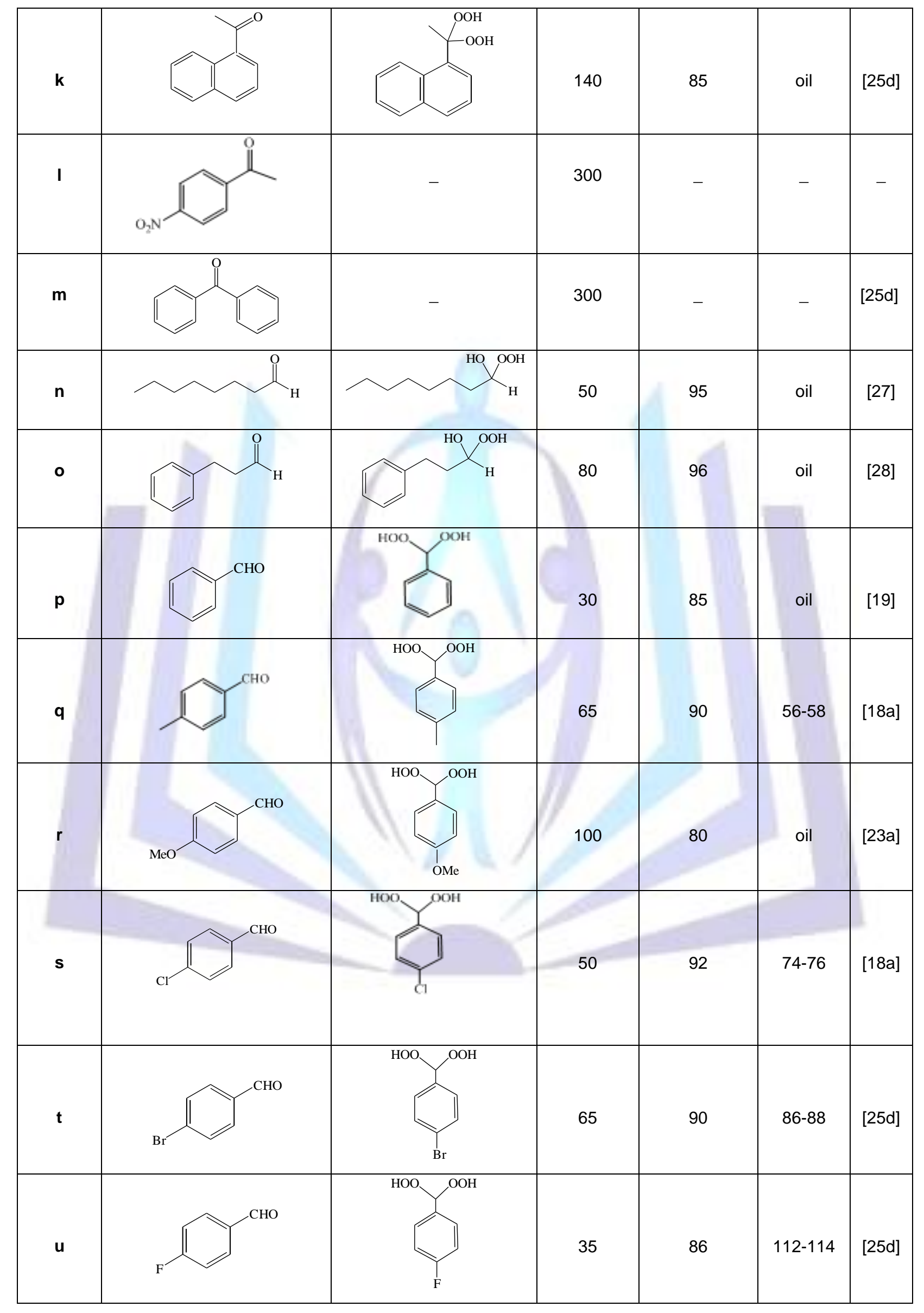




\begin{tabular}{|l|l|r|r|r|r|}
\hline & [25d] \\
\hline
\end{tabular}

A reasonable mechanism to explain the conversion of ketones and aldehydes 1 into respective gem-DHPs 2 is given in Scheme 2. As shown in this Scheme, the initial step likely involves the activation of carbonyl compound $\mathbf{1}$ through protonation with leucine carboxyl group. Then, the protonated carbonyl undergoes nucleophilic addition with deprotonated hydrogen peroxide to produce the adduct I. Subsequently, the resulting hydroxyl group in the intermediate I is protonated by leucine carboxyl group followed by nucleophilic substitution with a second molecule of hydrogen peroxide anion to furnish the product 2 .

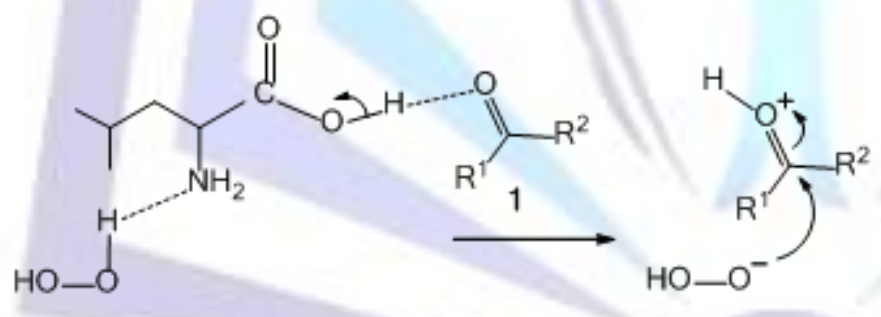<smiles>CCCOC(=O)C(CC(C)C)NOO</smiles>

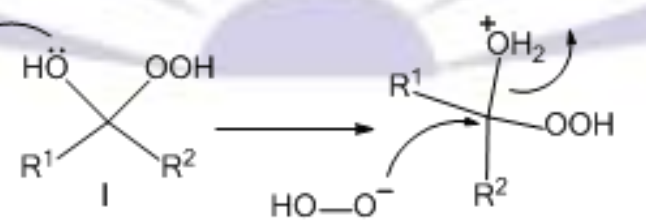

$\mathrm{HO}-\mathrm{O}^{-} \quad \mathrm{R}^{2}$

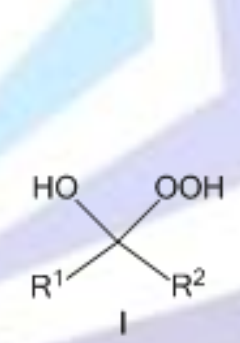

Scheme 2. Leucine-catalyzed synthesis of gem-dihydroperoxides from ketones and aldehydes.

\section{CONCLUSIONS}

In summary, Leucine amino acid has been explored as an efficient, reusable and green catalyst which can effectively accelerate the conversion of ketones and aldehydes into their corresponding gem-dihydroperoxides. These reactions proceed smoothly with low reaction times at room temperature to furnish the titled products in high to excellent yields.

\section{ACKNOWLEDGEMENT}

The authors are thankful to Bu-Ali Sina University Research Council for the financial support. 


\section{REFERENCES}

[1] Zmitek, K.; Zupan, M.; Iskra, J. Org. Biomol. Chem. 2007, 5, 3895.

[2] (a) Iskra, J.; Bonnet-Delpon, D.; Begue, J. P. Tetrahedron Lett., 2003, 44, 6309. (b) Tang, Y. Q.; Dong, Y. X.; Vennerstrom, J. L. Med. Res. Rev., 2004, 24, 425.

[3] (a) Dong, Y.; Mini-Re, V. Med. Chem., 2002, 2, 113. (b) Terent'ev, A. O.; Kutkin, A. V.; Starikova, Z. A.; Antipin, M. Y.; Ogibin, Y. N.; Nikishina, G. I. Synthesis, 2004, 2356. (c) Amewu, R.; Stachulski, A. V.; Ward, S. A.; Berry, N. G.; Bray, P. G.; Davies, J.; Labat, G.; Vivas, L.; O’Neill, P. M. Org. Biomol. Chem., 2006, 4, 4431.

[4] Terent'ev, A. O.; Platonov, M. M.; Tursina, A. I.; Chernyshev, V. V.; Nikishin, G. I. J. Org. Chem., 2008, 73, 3169.

[5] (a) Dussault, P. H.; Hu, C. Org. Lett., 2008, 10, 2401. (b) Zhang, Q.; Li, Y.; Wu, Y.-K. Chin. J. Chem., 2007, $25,1304$.

[6] Hamada, Y.; Tokuhara, H.; Masuyama, A.; Nojima, M.; Kim, H. S.; Ono, K.; Ogura, N.; Wataya, Y. J. Med. Chem., 2002, 45, 1374.

[7] (a) Kim, H-S.; Nagai, Y.; Ono, K.; Begum, K.; Wataya, Y.; Hamada, Y.; Tsuchiya, K.; Masuyama, A.; Nojima, M.; McCullough, K. J. J. Med. Chem., 2001, 44, 2357. (b) Masuyama, A.; Wu, J.-M.; Nojima, M.; Kim, H.- S.; Wataya, Y. Mini-Re, V. Med. Chem., 2005, 5, 1035.

[8] Hansma, H.; Schroeder, A. AKZO N. V. Belg. Patent 868,681, 1978; Chem. Abstr. 1979, 90, 153037a.

[9] Terent'ev, A. O.; Platonov, M. M.; Kutkin, A. V. Cent. Eur. J. Chem., 2006, 4, 207.

[10] (a) Jakka, K.; Liu, J.; Zhao, C. G. Tetrahedron Lett., 2007, 48, 1395-1398. (b) Aarifar, D.; Khosravi, K.; Synlett, 2010, 2755.

[11] Bunge, A.; Hamann, H-J.; McCalmont, E.; Liebscher, J. Tetrahedron Lett., 2009, 50, 4629-4632.

[12] (a) Jon Paul Selvam, J.; Suresh,V.; Rajesh, K.; Chanti Babu, D.; Suryakiran, N.; Venkateswarlu, Y.; Tetrahedron Lett., 2008, 49, 3463-3465. (b) Azarifar, D.; Khosravi, K.; Eur. J. Chem 1., 2010, 1, 15.

[13] (a) Ito, T.; Tokuyasu, T.; Masuyama, A.; Nojima, M.; McCullough, K. J. Tetrahedron, 2003, 59, 525. (b) Kim, H. S.; Nagai, Y.; Ono, K.; Begum, K.; Wataya, Y.; Hamada, Y.; Tsuchiya, K.; Masuyama, A.; Nojima, M.; McCullough, K. J. J. Chem. Soc., Perkin Trans. 1, $1999,1867$.

[14] Jefford, C. W.; Li, W.; Jaber, A.; Boukouvalas, J. Synth. Commun., 1990, 20, 2589.

[15] Terent'ev, A. O.; Kutkin, A. V.; Troizky, N. A.; Ogibin, Y. N.; Nikishin, G. I. Synthesis, 2005, 2215.

[16] Ledaal, T.; Solbjor, T. Acta Chem. Scand. 1967, 21, 1658.

[17] Kharasch, M. S.; Sosnovsky, G. J. Org. Chem., 1958, 23, 1322.

[18] (a) Zmitek, K.; Zupan, K.; Stavber, S.; Iskra, J. J. Org. Chem., 2007, 72, 6534. (b) Zmitek, K.; Zupan, K.; Stavber, S.; Iskra, J. Org. Lett., 2006, 8, 2491.

[19] Das, B.; Veeranjaneyulu, B.; Krishnaiah, M.; Veeranjaneyulu, B.; Ravikanth, B. Tetrahedron Lett., 2007, $48,6286$.

[20] Das, B.; Veeranjaneyulu, B.; Krishnaiah, M.; Balasubramanyam, P. J. Mol Catal A: Chem, 2008, 284, 116.

[21] Bunge, A.; Hamann, H. -J.; Liebscher, J. Tetrahedron Lett., 2009, 50, 524.

[22] Ghorai, P.; Dussault, P. H. Org. Lett., 2008, 10, 4577.

[23] (a) Li, Y.; Hao, H. -D.; Zhang, Q.; Wu, Y. Org. Lett., 2009, 11, 1615.

[24] P. T. Anastas, J. C. Warner, Green Chemistry: Theory and Practice, Oxford University Press, New York, 1998, p. 30.

[25] (a) Azarifar, D.; Khosravi, K.; Soleimanei, F. Synthesis, 2009, 15, 2553. (b) Azarifar, D.; Khosravi, K.; Soleimanei, F. Molecules, 2010, 15, 1433. (c) Azarifar, D.; Khosravi, K. J. Iran. Chem. Soc. 2011, 8, 1006. (d) Azarifar, D.; Najminejad, Z.; Khosravi, K. Synth. Commun. 2013, 43, 826.

[26] (a) Azarifar, D.; Khosravi, K.; Najminejad, Z. J. Iran. Chem. Soc. 2013, 10, 979. (b) Azarifar, D.; Khosravi, K.; Najminejad, Z.; Soleimani, K. J. Iran. Chem. Soc. 2012, 9, 321. (c) Azarifar, D.; Khosravi, K. Eur. J. Chem. 2010, 1 , 15. (d) Azarifar, D.; Khosravi, K.; Synlett 2010, 2755. (e) Azarifar, D.; Najminejad, Z. Synlett 2013, 1377. (f) Azarifar, D.; Khatami, S.M.; Najminejad, Z. J. Iran. Chem. Soc. 2014, 11, 587. (g) Azarifar, D.; Khosravi, K.; Najminejad, Z.; Soleimani, K. Heterocycles 2010, 81, 2855. (h) Azarifar, D.; Najminejad, Z. Khosravi, K. Synth. Comm. 2013, 43, 826.

[27] Wei, Z.; Xu, C.; Li,B. Bioresource Technology, 2009, 100, 2883.

[28] Rieche, A. Chem. Ber., 1931, 64, 2328. 